\title{
The Origins of Multinational Manufacturing by Continental European Firms*
}

a European multinationals followed a different path of development from that pursued by United States firms, but European multinational manufacturing began even earlier than did American, and its story is no less significant. Dr. Franko offers a range of relevant data and analysis about the evolution of direct foreign investment by Western European manufacturers.

Unlike its European counterpart, the origins of the spread of U.S. multinational manufacturing enterprise are reasonably well understood. It seems generally agreed that American firms started down the road to multinational manufacturing because they had a penchant for introducing new, labor-saving, highly income elastic products; they specialized in what has come to be termed "product pioneering." As innovators, they had proprietary knowledge of the production of these goods, which were clearly differentiable from other articles because of their novelty. ${ }^{1}$ Rising per capita incomes in Europe and elsewhere first pulled such new products into those nations as exports. ${ }^{2}$ When income distributions in Europe shifted toward the U.S. pattern, as they did in post-World War II Britain, Sweden, and Holland, the pull was probably all the

Business History Review, Vol. XLVIII, No. 3 (Autumn, 1974). Copyright (C) The President and Fellows of Harvard College.

- The research on which this article is based was made possible by the financial support of the Ford Foundation, the Centre d'Etudes Industrielles, and the Harvard Business School. It was done as part of the Harvard-CEI comparative multinational enterprise study of the foreign operations of the world's largest manufacturing enterprises.

IIn this paper, "innovation" refers to first commercial introduction, rather than first invention of a product.

The relationship between differentiability of products and the spread of foreign manufacture "horizontally," i.e., in the same product lines, by U.S. firms, has been particularly emphasized by Caves. See R. Caves, "International Corporations: The Industrial Economics of Foreign Investment," Economica (Febnuary, 1971).

${ }^{2}$ Empirical evidence for this view of the causes of U.S. foreign investment is accumulating at a rapid rate. For example, A. E. Scaperlanda and L. J. Maurer have shown that changes in EEC market size, not trade barriers nor differential U.S.-EEC growth rates were most closely correlated with the massive influx of American direct investment in Europe between 1952 and 1966. See Scaperlanda and Maurer, "The Determinants of U.S. Direct Investment in the EEC," American Economic Review (September 1969). See also the evidence summarized in Raymond Vernon, Sovereignty at Bay (New York, 1971), Chapter III. 
harder. ${ }^{3}$ The American Challenge thus met the European attraction, most often in the form of foreign customers' requests. ${ }^{4}$

For American firms, the transition from exporting to foreign manufacturing often came as non-American markets for new products became large enough and certain enough to warrant investments in additional plant capacity. Foreign production seemed in order when scale economies in U.S. production were about to be exhausted, when foreign production began to look as if it could be undertaken for an average cost less than U.S. marginal cost plus transport and tariffs, and when customer needs and production techniques were standardized so that such costs could be calculated. All these events inevitably occurred as new products went from birth to maturity over their life cycles. ${ }^{5}$ They were hastened by the fact that wage rates were almost invariably lower outside, as opposed to inside the U.S. In such circumstances, even profit maximizing firms with world-wide product monopolies had reason to put up foreign plants. Conceptually, their decision was identical to that of a domestic manufacturer considering expansion into a less developed region of his home market. The evidence suggests, however, that managers of few U.S. firms reasoned in quite such a comfortable manner. The threat of losing established markets, rather than opportunities offered by new ones, was the most frequent trigger of foreign manufacturing investment. ${ }^{6}$ Even in the early days of their international export expansion, most U.S. firms were threatened by competition, either from local entrepreneurs awakening to newly feasible production opportunities, ${ }^{7}$ or (more importantly) from either potential or actual threatening moves by American oligopolistic competitors. ${ }^{8}$

Much less is known about the evolution of European-based multinationals. Indeed, even the magnitude of those "other multinationals" has often remained obscure. During the 1960 s it was

3 This hypothesis has been subjected to a very preliminary (although positive) test in J. Neill Fortune, "Income Distribution as a Determinant of Imports of Manufactured Consumer Commodities," Canadian Journal of Economics, V (May, 1972).

"The importance of foreign customers' requests as a factor pulling U.S. firms into foreign markets has been repeatedly emphasized in surveys of motivations both for exporting and for foreign manufacturing investments. H. J. Robinson, in The Motivation and Flow of Foreign Private Investment (Stanford Research Institute, 1961), 37, notes that over 90 per cent of external triggers for investment mentioned by U.S. firms in his survey involved proposals by foreign industrialists.

A further description of this process is given in Raymond Vernon, "International Trade and International Investment in the Product Cycle," Chapter II of Sovereignty at Bay.

See Ibid., Chapter 3 for evidence on this point.

7 Ibid.

${ }^{8}$ See Frederick T. Knickerbocker, Oligopolistic Reaction and Multinational Enterprise (Boston, 1973), for statistical evidence. See also Mira Wilkins, The Maturing of Multinational Enterprise (Cambridge, Mass., 1974) for historical material on specific firms. 
sometimes said that virtually all multinational enterprises were American in origin. ${ }^{9}$ However, the historical record shows that multinationality of manufacturing operations is no American monopoly. ${ }^{10}$ During the century and a half that has elapsed since Cockerill of Belgium put up its first foreign plant in Prussia in 1815, the majority of today's large Western European companies have come first to sell and then to produce outside their home countries.

In 1970, seventy-eight of the eighty-one continental European companies on the Fortune " 200 " list were manufacturing outside their home countries. Even "domestic" coal and steel producers such as Buderus'che, Salzgitter, Vallourec, and Charbonnages de France, owned at least 25 per cent of one or more foreign manufacturing ventures in that year. Moreover, some sixty of the seventyone firms for which information is available derived 25 per cent or more of their total sales from exports and foreign production in $1970 .^{11}$

Already in 1960 , thirty-four of the eighty-one large continental firms owned manufacturing operations in seven or more countries. ${ }^{12}$ On the eves of World Wars 1 and II, the number of such firms, or of their direct predecessors with a corresponding degree of multinationality, had been seven and fourteen respectively. By 1970 , no fewer than sixty-two of the eighty-one European companies on the Fortune " 200 " list had attained such a multinational spread. The distribution of the continental companies by industry and by degree of multinationality in 1970 is given in Table 1.

- Such at least was the implication most readers carried away from a reading of $\mathrm{J}$. $\mathrm{J}$. Servan-Schreiber's famous statement that, after the U.S. and the U.S.S.R., the third largest producing unit in the world would soon consist of American subsidiaries abroad. The impression was made all the stronger by chapter titles such as "Europe Without a Strategy" and by sentences such as: "L'Europe n'a presque rien sur le plan industriel, de comparable aux entreprises à grande aire d'activité qui caractérisent les sociétés américaines s'implantant sur son sol. Une exception intéressante: L'Imperial Chemical Industries (Angletrre), seule compagnie européenne qui ait organisé un état-major à l'échelon du continent pour prendre en main l'administration de ses cinquante filiales. Les efforts déployés par quelques autres sociétés européennes apparaissent timides." Servan-Schreiber, Le Défi Américain (Paris, 1967), 20, emphasis added.

In 1969, Jack Behrman also appeared to underestimate the importance of European companies" international operations: "If one postulates that the awakening point (of transition to multinational enterprise) occurs when foreign operations become something over 25 percent of total activity of the enterprise, there are close to 200 U.S.-based enterprises which are candidates for becoming multinational - if they are not already in that category. But, there are few European-based companies meeting the criterion." Behrman, Some Patterns in the Rise of Multinational Enterprise (Chapel Hill, N.C., 1969).

10 The word "multinational" as used here only denotes the existence of manufacturing operations, owned to significant extent by the parent firm, in numerous countries.

11 Company annual reports and documents.

12 Manufacturing operations were counted as belonging to a particular European company if they were 25 per cent or more owned by it. Source: Tabulation done by the author from company reports and partly reported in L. G. Franko, "Multinational Corporations in the 1970's: Will They Matter?" in P. Uri, ed., Trade and Investment Policies for the 1970's (New York, 1971). 
TABLE 1

Multinationality of European Enterprise, 1970

(Distribution of the 81 lateest Continental European

Manufacturing Enterprises by Main Industry of Production

and by Extent or Foreign Manufacture, 1970)

\begin{tabular}{|c|c|c|c|}
\hline $\begin{array}{l}\text { SIC } \\
\text { No. }\end{array}$ & $\begin{array}{l}\text { Main Industry } \\
\text { of Firm }\left({ }^{*}\right)\end{array}$ & $\begin{array}{c}\text { Number of } \\
\text { Firms In } \\
\text { Sample }\end{array}$ & $\begin{array}{l}\text { Number of Firms } \\
\text { with Manufactur- } \\
\text { ing Operations } \\
\text { in } 7 \text { or more } \\
\text { Countries at End } \\
\text { of } 1970 \text { ) }\end{array}$ \\
\hline 20 & Food and Beverages & 2 & 2 \\
\hline $24-27$ & $\begin{array}{l}\text { Wood, Paper and Printing } \\
\text { products }\end{array}$ & 3 & 2 \\
\hline 28 & Chemicals and Pharmaceuticals & 14 & 14 \\
\hline 284 & Soaps and Toiletries & 1 & 1 \\
\hline 29 & Petroleum & 6 & 6 \\
\hline 299 & Coal products & 1 & 0 \\
\hline 30 & Rubber & 3 & 3 \\
\hline 32 & Glass & 2 & 2 \\
\hline 331 & Primary Ferrous Metals & 15 & 6 \\
\hline 333 & Primary non-Ferrous Metals & 7 & 5 \\
\hline 35 & Non-Electrical Machinery & 7 & 5 \\
\hline \multirow[t]{2}{*}{$361-2$} & Industrial Electrical & & \\
\hline & Machinery & 6 & 6 \\
\hline \multirow[t]{2}{*}{$363-9$} & Consumer Electrical and & & \\
\hline & Electronic products & 4 & 4 \\
\hline \multirow[t]{2}{*}{37} & Transportation equipment & 10 & 6 \\
\hline & Total & $\overline{81}$ & $\overline{62}$ \\
\hline
\end{tabular}

(*) Defined as the indicated Standard Industrial Classifications (SIC) industry in which firms had the largest portion of their sales.

(*) Firms were counted as having manufacturing operations in a given country only if they owned 25 per cent or more of a manufacturing subsidiary in it.

Many continental European companies have been active in international manufacturing for a very long time. A significant number of today's major European chemical, pharmaceutical, electrical equipment, and food companies had some manufacturing outside their home countries by World War I. ${ }^{13}$

The earliest pioneers are cited in Table 2. Out of a total of seventeen, nine were German. By and large, when they undertook foreign manufacturing, they did so in other European countries. Eight were based in the chemical industry, and four produced elec-

13 Information in the Comparative Multinational Enterprise Data Bank, Harvard Business School; see also sources for Table 2. 
trical equipment. European multinational enterprise was beginning to emerge at least as early as the American variety. ${ }^{14}$

During the inter-war period, these international enterprises were in turn joined by others. Dutch, Swiss, and Swedish newcomers such as Philips, Margarine Uni, Alusuisse, and Swedish Match were perhaps the most prominent additions in those years. A number of inveterate German internationalizers (I. G. Farben, Bosch, Siemens, and AEG) were stubbornly reconstituting the foreign outposts lost in World War I. They were to do so once again after their foreign manufacturing subsidiaries had again been confiscated during World War II.

The major expansion in the number of European companies with significant multinational operations, to be sure, occurred in the postWorld War II era. Despite early efforts such as Renault's establishment of two assembly plants in Russia in 1914, Europe's automobile companies were to have significant international manufacturing activities only after 1946.15 Anglo-Dutch Shell excepted, continental European petroleum companies with important international operations emerged only during the 1950s. In sectors such as electrical and non-electrical machinery, the few firms with lengthy international experience, such as Siemens, AEG, and Bosch of Germany were joined by a host of newcomers, including ThomsonBrandt of France and Olivetti of Italy. Nevertheless, neither the state nor the process of multinationality are unusual for European enterprise.

\section{Proliferation of Foreign Manufacturing Subsidiaries}

The spread of foreign manufacturing by the large firms of continental Europe has, however, been anything but gradual. If a look at the numbers of parent firms with international operations could convey an impression of a smooth European expansion into multinationality, a quite different picture is painted by the record of foreign subsidiaries set up or acquired. Table 3 suggests that the numbers of entries into subsidiaries by continental parents have alternately expanded very rapidly or stagnated. The number of foreign manufacturing outposts of continental firms proliferated just before and just after World War I. The next great spurt did

14 On the pre-World War I U.S. multinational company expansion, see Mira Wilkins, The Emergence of Multinational Enterprise (Cambridge, Mass., 1970), especially 212 and 213.

15 Patrick Fridenson, Histoire des Usines Renault (Paris, 1972), 66. One of Renault's factories was located in Petrograd (later Leningrad). 


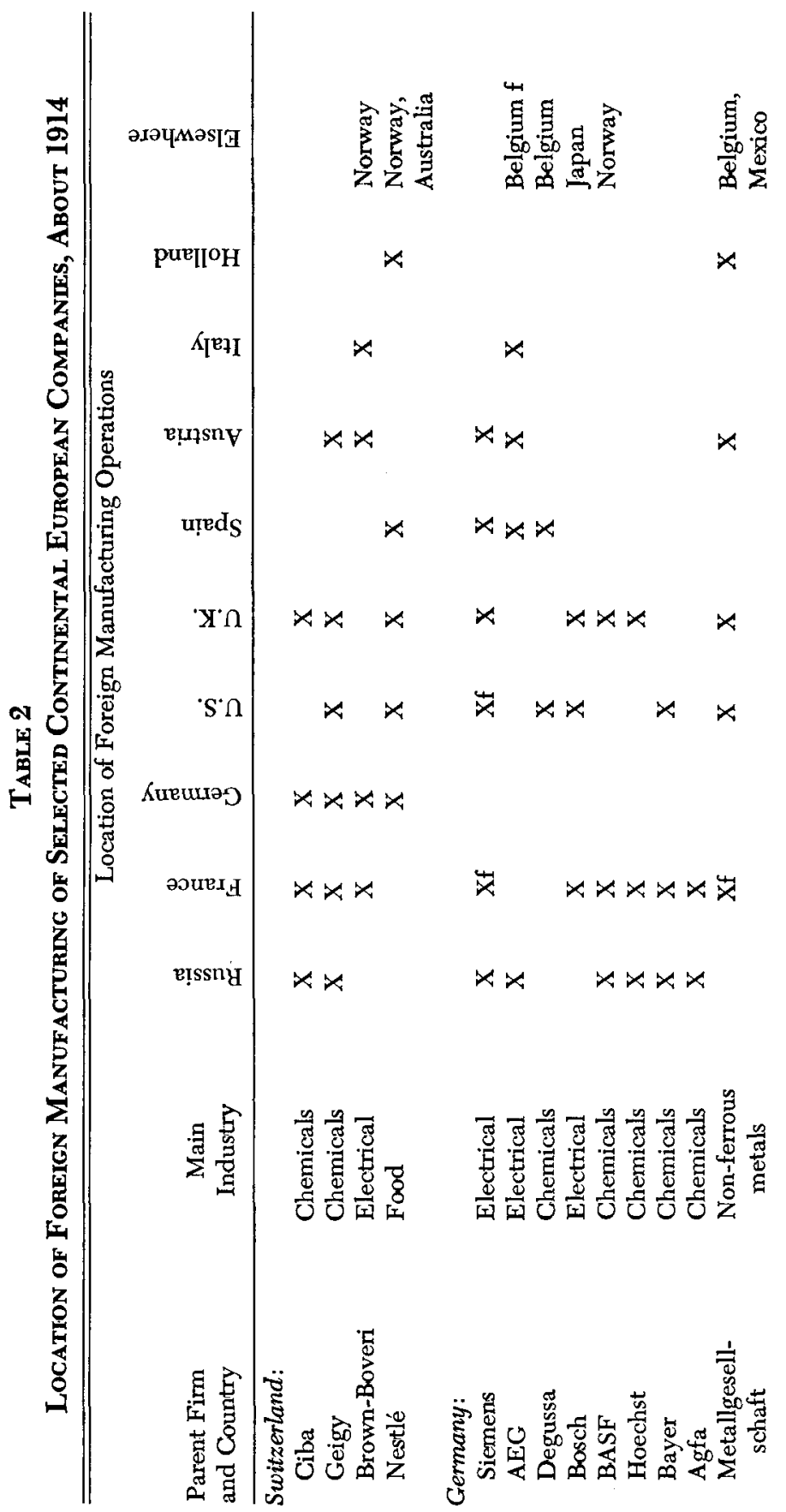

282 BUSINESS HISTORY REVIEW

Downloaded from https:/www.cambridge.org/core. University of Basel Library, on 10 Jul 2017 at 16:17:17, subject to the

Cambridge Core terms of use, available at https:/www.cambridge.org/core/terms. https://doi.org/10.2307/3112950 


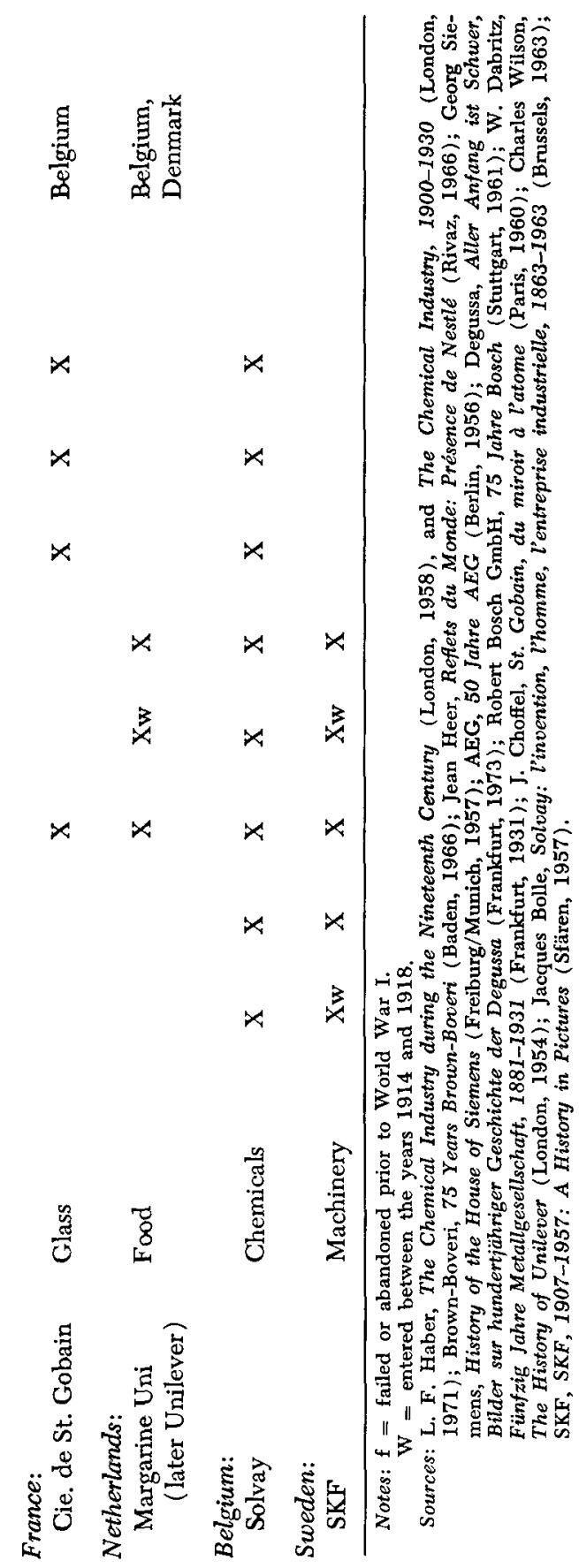

EUROPEAN MULTINATIONALS 
not occur until the late 1960s, as is shown in Table 3. This was quite a different evolution from the continually increasing expansion of U.S. company subsidiaries documented in the same table.

TABLE 3

Entry Into Foreign Manufacturing: Comparative Histories of U.S., British, Continental European and Japanese Enterprise

\begin{tabular}{|c|c|c|c|c|}
\hline Period & \multicolumn{4}{|c|}{$\begin{array}{c}\text { Numbers of Foreign Manufacturing } \\
\text { Subsidiaries Entered by Parents from: } \\
\text { Continental }\end{array}$} \\
\hline Pre-1914 & 122 & 60 & 167 & 0 \\
\hline $1914-1919$ & 71 & 27 & 51 & 0 \\
\hline $1920-1929$ & 299 & 118 & 249 & 1 \\
\hline $1930-1938$ & 315 & 99 & 112 & 3 \\
\hline $1939-1945$ & 172 & 34 & 44 & 40 \\
\hline 1946-1952 & 386 & 202 & 129 & 2 \\
\hline $1953-1955$ & 283 & 55 & 117 & 5 \\
\hline 1956-1958 & 439 & 94 & 131 & 14 \\
\hline $1959-1961$ & 901 & 333 & 232 & 44 \\
\hline 1962-1964 & 959 & 319 & 229 & 90 \\
\hline 1965-1967 & 889 & 459 & 532 & 113 \\
\hline $1968-1970$ & n.a. & 729 & 1,030 & 209 \\
\hline
\end{tabular}

Notes: Data on subsidiaries of U.K., continental European, and Japanese-based firms were collected for all 200 parent firms on the 1971 Fortune " 200 " list of non-U.S. industrial enterprises, as well as for a few financial holding companies and family groups that had more than $\$ 400,000,000$ of sales in 1970 coming from manufacturing operations. Data on subsidiaries of U.S.-based parents were collected for 187 U.S. firms on the 1968 Fortune " 500 " list with an equity interest of at least 25 per cent in manufacturing subsidiaries in at least six foreign countries as of January 1, 1968. Some fifty of these U.S. firms were smaller than the non-U.S. companies surveyed. A similar number of non-U.S. firms do not manufacture in six or more foreign countries. Data incomparabilities thus exist. They do not, however, seem critically to alter the order of magnitude indicated by the above comparisons. For a fuller explanation of the data in the Comparative Multinational Enterprise Data Bank, see the Vaupel and Curhan book.

Source: James W. Vaupel and Joan P. Curhan, The Making of Multinational Enterprise (Harvard Business School, Boston, 1973, and C. E. I., Geneva, 1974), Tables 1.17.2, 1.17.3, 1.17.4, and 1.17.5, pages 72-103.

\section{TeChNological InNovations and Exports}

If the spread of European multinational company activity was unique in its timing, most of it nonetheless had origins that appeared to resemble those of U.S. multinational expansion in one critical respect. Like their U.S. counterparts, continental European manufacturing firms almost always seem to have begun the process of becoming multinational by exporting on the basis of oligopolistic advantages in technological innovation. ${ }^{16}$ Yet, the

${ }^{10}$ As indicated above, the word innovation as used here signifies first commercial introduction, not invention. European inventors often preceded American innovation, as Table 
kinds of oligopolistic innovations developed by Europe's nascent multinationals tended to be quite unlike those first commercialized in the U.S. market.

As in the case of U.S. exports that later led to multinational production, it was innovation, or first commercial introduction, that mattered, not first invention. European invention, that is to say, discovery, often led neither to home nor export sales. On the contrary, European inventions were often transferred to the U.S. and first applied there. ${ }^{17}$ The examples of penicillin, the computer, and the integrated circuit are cases in point. Even within the European context, the same phenomenon could be observed, for example in the invention of margarine in France followed by first commercial introduction in Holland. ${ }^{18}$

Examples of the connection between continental European innovation, exports, and subsequent foreign production are numerous and convincing, despite the fact that the link has not been rigorously demonstrated. The history of synthetic dyestuffs is another case in point. Table 2 above indicated that numerous foreign manufacturing operations had been begun before 1914 by dyestuffs firms such as Ciba, Geigy, BASF, Hoechst, Bayer, and Agfa. L. F. Haber, H. Friedlander, and others have chronicled how, prior to this multinational spread, the invention of synthetic dyestuffs in England and France was followed not by English and French exports, but rather by large-scale commercialization and process and product development in Germany and Switzerland. Massive exports, and then industrial implantation back into the countries of invention later emanated from the innovating German and Swiss enterprises. ${ }^{19}$ Something of the export phase of this sequence

4 points out. It was typically this innovative step that led to the rise of multinational enterprise. The role of oligopolistic competitive advantage and market imperfection in explaining the rise of multinational enterprise was first examined systematically in $S$. Hymer, "The International Operations of National Firms: A Study of Direct Investment," (Doctoral dissertation, Massachusetts Institute of Technology, 1960). The importance of oligopolistic imperfections based on technology in explaining the international spread of U.S. enterprise has been the subject of a vast and growing literature. See inter alia: $R$. Vernon, "International Investment and International Trade in the Product Cycle," Quarterly Journal of Economics (May, 1966), and the studies included and cited in L. T. Wells, Jr., ed., The Product Life Cycle and International Trade (Boston, 1972). See also: A. Harmann, The International Computer Industry (Cambridge, Mass., 1970); and Harvard Business School, "The U.S. Automobile Industry in the World Market," Note ICR 530, 1971.

${ }^{17}$ No systematic study of the frequency or causes of the international transplant of inventions appears to have been made. But examples of European inventions followed by U.S. application are abundant enough. See David Landes, The Unbound Prometheus (Cambridge, 1969); OECD, Gaps in Technology, Vols. I-V (Paris, 1971); J. Jewkes, et al., The Sources of Invention (London, 1969).

${ }^{18}$ Charles Wilson, The History of Unilever (London, 1954) II, 25 and 26.

${ }^{19}$ L. F. Haber, The Chemical Industry in the Nineteenth Century (London, 1958); H. Friedlander and J. Oser, Economic History of Modern Europe (New York, 1953), especially 243. 
prior to World War I can be glimpsed from Table 4 below. The impression of a connection between innovation and exports becomes still stronger upon noting that synthetic dyestuffs exports from firms in countries other than Germany and Switzerland were virtually nil. ${ }^{20}$

TABle 4

Growth of THE Synthetic DyestufF INDUSThy

\begin{tabular}{cccccc}
\hline \multicolumn{1}{c}{$\begin{array}{c}\text { Dyestuff Patents } \\
\text { Granted in } \\
\text { England to: }\end{array}$} & $\begin{array}{c}\text { Number of } \\
\text { Employees } \\
\text { of the } \\
\text { "Badische }\end{array}$ & & \\
Quinquennia & $\begin{array}{c}\text { German } \\
\text { Ending: }\end{array}$ & $\begin{array}{c}\text { British } \\
\text { Inventors }\end{array}$ & $\begin{array}{c}\text { Anilin und } \\
\text { Inventors }\end{array}$ & Sodafabrik" & Exports in Metric Tons: \\
Germany & Switzerland \\
\hline 1860 & 8 & 20 & & & \\
1880 & 47 & 13 & 1,534 & 8,294 & \\
1900 & 427 & 52 & 6,711 & 46,858 & 3,116 \\
1910 & 561 & 30 & 7,610 & 84,110 & 6,975 \\
\hline
\end{tabular}

Source: Encyclopaedia of the Social Sciences, V, 302.

Innovative advantages also appeared intimately linked with the extraordinary export successes of Germany's Siemens and AEG. Some of their innovative advantages were indigenous, others originated with exclusive European licenses from U.S. companies for the production of electric lights, automatic telephone exchange, and the like. On the eve of World War I, Germany accounted for over 48 per cent of total world electrical exports. ${ }^{21}$ Indeed, Germany remained the largest single exporting country for electrical equipment until the outbreak of World War II. ${ }^{22}$ Exports of unique goods, or goods produced with unique processes, preceded essentially all the pre-World War II expansion by Siemens and AEG into foreign manufacturing (noted in Table 2). Only one important exception appeared: Siemens quite unusually began the production of telegraph cables and water meters in England in the $1850 \mathrm{~s}$ - products the firm did not then manufacture at home. ${ }^{23}$

A link between innovation and export can be found in the histories of virtually all the other parent firms prominent in the expansion of European multinationals before World War II. The formation of Ivar Kreuger's Swedish Match empire in the 1920s

\footnotetext{
${ }^{20}$ Haber, Chemical Industry in the Nineteenth Century, 243.

21 Friedlander and Oser, Economic History, 247.

${ }^{22}$ Georg Siemens, History of the House of Siemens (Freiburg and Munich, 1957), II.

${ }^{23}$ Ibid., I, 32ff.; AEG, 50 Jahre AEG (Berlin, 1956).
} 
followed a half century of Swedish exports based on innovations in safety matches. ${ }^{24}$ Alusuisse had been the first firm formed to exploit the Herault process for producing aluminum. It exported aluminum for many years prior to entering significant foreign production. $^{25}$ I. G. Farben earned much foreign exchange for Weimar and then for Nazi Germany by first spending up to 12.7 per cent of its sales revenue (in 1927) on research and development in order to secure innovative advantages. ${ }^{26}$ By 1908, Philips of Holland had ceased simply imitating carbon filament electric lamps and exporting only on the basis of a price advantage secured through relatively low cost labor. Development efforts underlay increasing product and process singularity that in turn preceded Philips' major moves into foreign manufacturing in the 1930s. ${ }^{27}$

After World War II much the same sort of sequence seemed again in motion. The distinctive post-1945 European innovations in autos, pharmaceuticals, plastics, and metalworking processes, cited in Table 5, led first to exports, and only then to production abroad. There were, however, some exceptions to the rule, and perhaps the most notable were the petroleum companies started and owned by governments in France and Italy.

Western Europe, as it again abruptly came to realize in the 1970s, has never had the indigenous resources of petroleum that allowed U.S. firms to develop innovative advantages in refining - let alone exploration - comparatively quickly. Of the continental countries, only Holland had oil-producing colonies during the first half of the twentieth century. After the Russian Revolution eliminated foreign-owned firms from the Caucasus, Western European governments felt dependent on either Anglo-Saxon companies (and on the partly British Royal Dutch Shell) or the Soviet government for their oil supply. Some were content with neither choice. One result was what the historian of the Compagnie Française des Pétroles refers to, in jest, as the "immaculate conception" of that firm out of the debris of World War I. ${ }^{28}$ The company was formed at the initiative of the French government to administer that part of the Turkish Petroleum Company (later the Iraq Petroleum Company)

\footnotetext{
24 Friedlander and Oser, Economic History, 417.

${ }^{25}$ D. H. Wallace, Market Control in the Aluminum Industry (Cambridge, Mass., 1937), $6,33,34$.

${ }^{28}$ H. Gross, Further Facts and Figures on I. G. Farben (Kiel, 1950), 12.

${ }_{27}$ N. V. Philips, Facts About Philips (Eindhoven, 1970), 3-8; P. J. Bouman, Anton Philips of Eindhoven (London, 1958), 48, mentions Philips" original low wage competitive advantage. The book subsequently describes its move toward its own proprietary technology.

${ }_{28}$ Jean Rondot, La Compagnie Française des Pétroles (Paris, 1962 ), 5.
} 


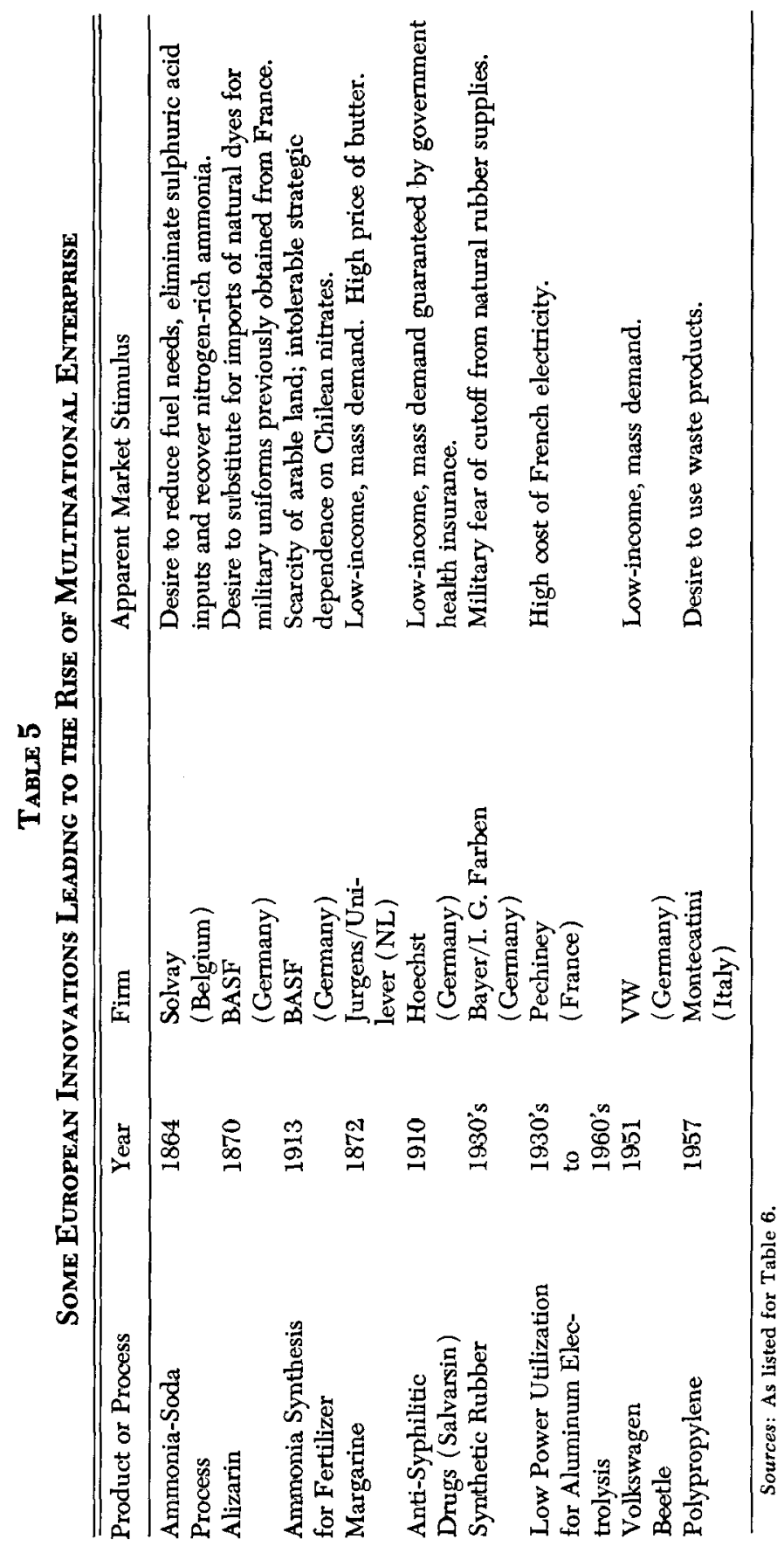

288 BUSINESS HISTORY REVIEW 
awarded to France at the San Remo Diplomatic Conference as part of the spoils of World War I. ${ }^{29}$ After oil was discovered, CFP's British and American partners in IPC built a refinery in Iraq to process the crude. Thus, politics (and a cash contribution) first put the now multinationally active CFP into the business of both foreign manufacturing (i.e., oil refining) and exporting refined petroleum products. With the experience thus gained, and later with a protected home market as well, such a government-instrument firm could subsequently apply lessons learned in its hothouse environment to foreign countries in the manner of a more "spontaneously generated" multinational. Indeed, even if it never developed marked oligopolistic technological advantages by this process, such a firm could, and often did, offer a differentiated, non-Anglo-Saxon "political" product. ${ }^{30}$

\section{The Role of Home Market Conditroning}

More than "immaculate conceptions" have, however, set the story of the spread of continental European multinational enterprise apart. Early home market conditioning seems to have played a considerable role. It is clear that the economic characteristics of home markets in continental Europe were different from those facing innovators in the U.S. Distinctive home markets appear to have left their mark on Europe's nascent multinationals primarily in terms of the kinds of product and process innovations they developed. The frequency distribution of European innovations eventually put into foreign production appears to have long been biased toward material-saving processes, ersatz material substitutes, and goods oriented toward low-income consumers. This tendency is illustrated in Table 5. By way of contrast, the examples presented in Table 6 indicate that U.S. innovations were typically skewed towards goods and processes that had an appeal to the unique high-income, labor short American market.

\section{Conditioning By Different Income Levels}

Part of the explanation for differences between European and American patterns of innovation doubtless lies in differences in

20 Ibid., IIff,

${ }^{30}$ ENI, the Italian state oil company in particular appears to have gained entry into refining in various countries in Africa largely as a result of such political product differentiation. See M. Tiger and L. G. Franko, E.N.I. (Geneva, 1973); P. Frankel, Mattei: Oil and Power Politics (New York, 1966); Elena Chiado-Fiorio, Il Caso ENI (Torino, 1973). 


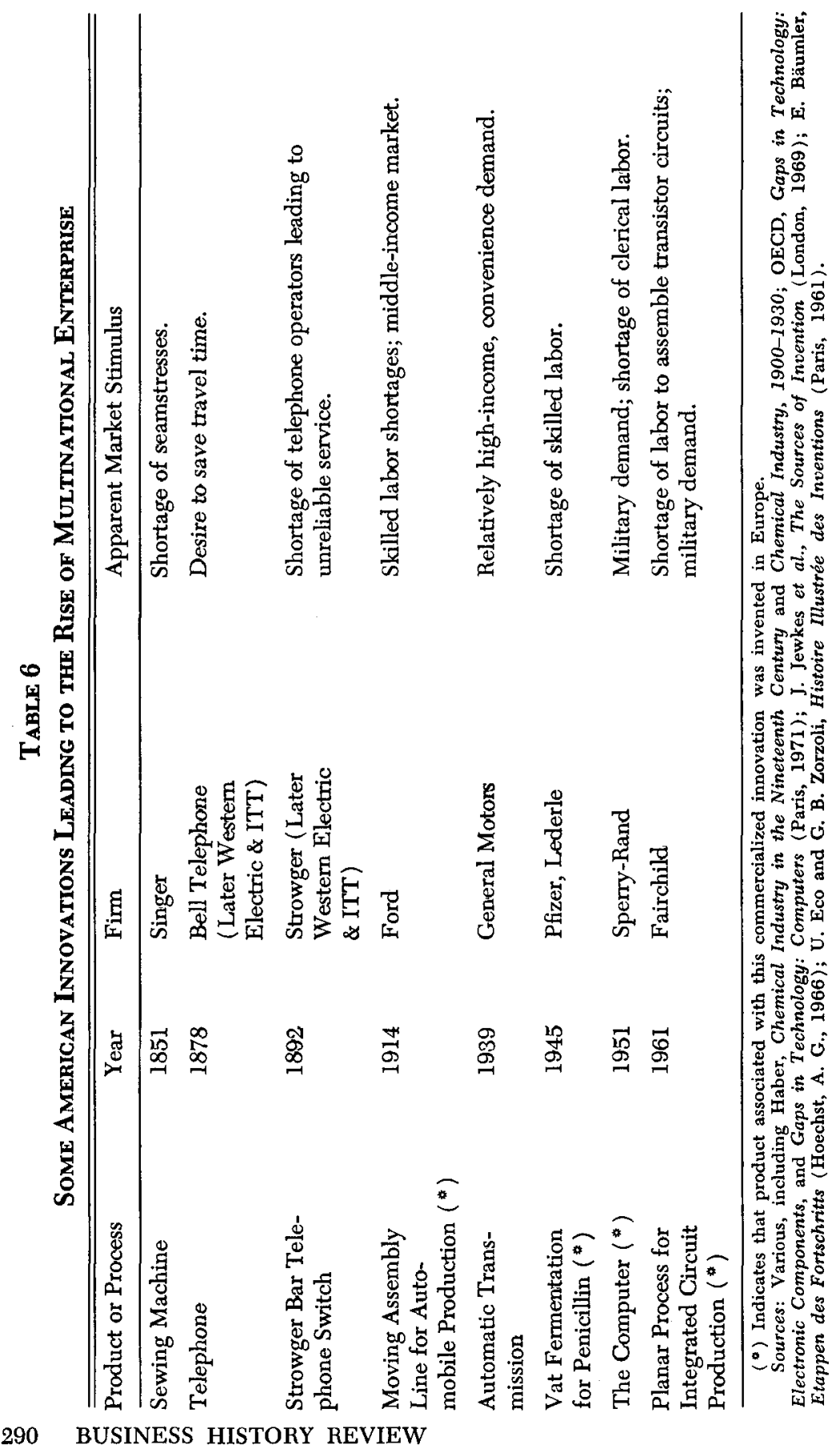


absolute levels of income per capita. Average national income per capita data for ten countries in 1914 are presented in Graph 1. Graph 2 presents similar data for twenty-four of the world's 186 nations for 1959 and 1969. These tables show that the U.S. was highest on the list for both 1914 and 1969. Moreover, the relative rankings of income levels for the U.S., France, Germany, and Italy did not change over this fifty-five-year span. Even changes in proportional differences have not been great. U.S. per capita income throughout the first half of the twentieth century was nearly twice that of France and Germany, and roughly three times that of Italy. Some nations have changed their relative positions for the better (Japan) or worse (the U.K.), but the relationship between the U.S. and the largest continental countries has remained relatively stable.

International differences in income levels are important for innovative activity because consumers appear to behave as if they have a hierarchy of needs varying with their income levels. Evidence suggests that the order in which consumers acquire house-

GRAPH I

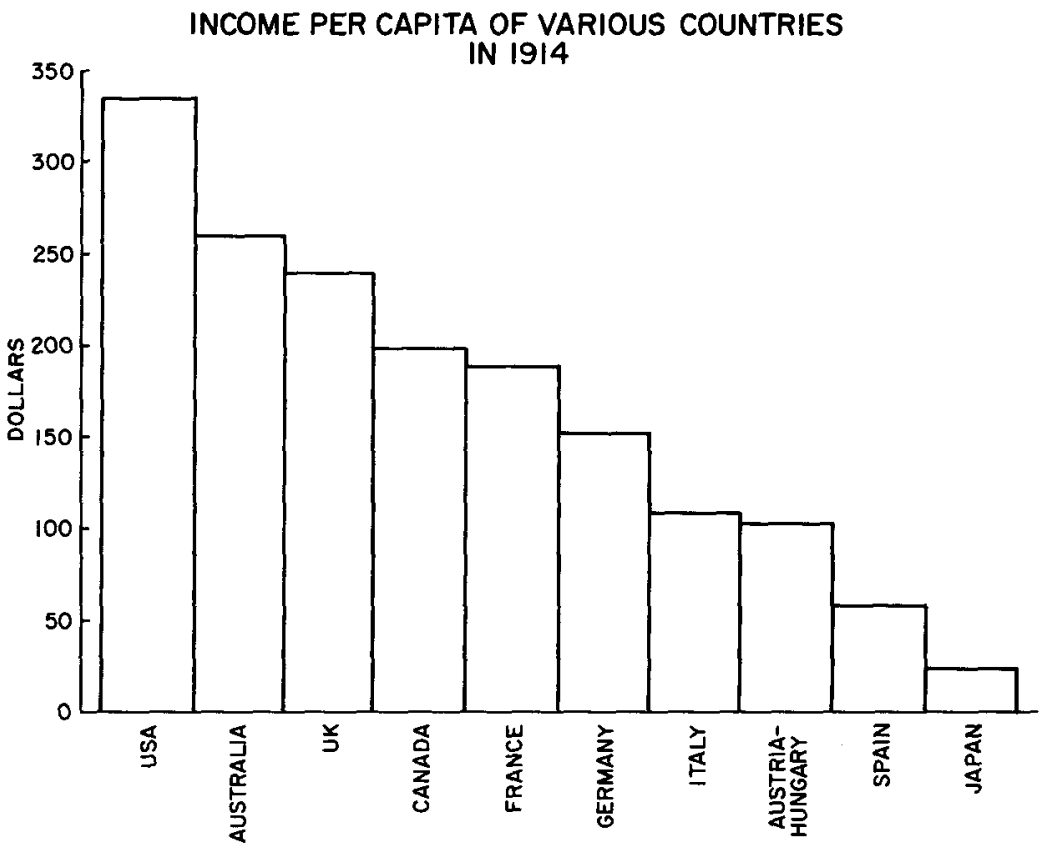

Source: National Bureau of Economic Research, Income in the United States: Its Amount and Distribution, 1909-1919 (New York, 1921), I. 


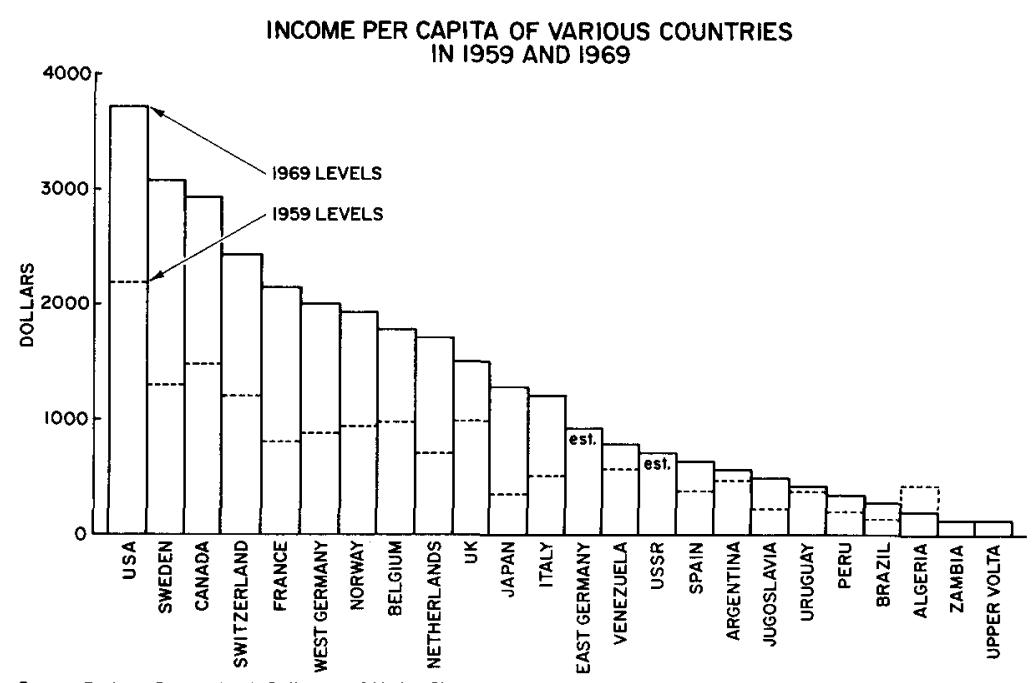

Source: Business Intemotional, Indicators of Market Size, vorious issues.

hold appliances is primarily a function of income, rather than of broad cultural factors. ${ }^{31}$ Setting aside obvious differences due to resource endowments, it also appears that there is an order of acquisition of industrial goods that is followed fairly predictably as a result of economic growth. ${ }^{32}$ By extension, one expects new needs to emerge as incomes grow to previously unreached levels. If scientific and technical skills are available, would-be innovators will presumably respond to such new needs. Moreover, would-be innovators located in a "first market" seem to have an enormous advantage over those located outside it. It is they who will be most conscious of the emergent market opportunity; it is they who can most rapidly respond to customer wants and define concretely a product that at first may be only a hazy, uncertain idea. ${ }^{33}$

Given the historical constants shown in Graphs 1 and 2, it is understandable that the U.S. market long acted as midwife to the development by U.S. companies of the time-saving, convenience products that substituted for high-income, high-cost labor. ${ }^{34}$ The

${ }^{31}$ See, for example, Y. Parush, "The Order of Acquisition of Durable Goods," Bank of Israel Bulletin (February, 1964).

32 Such appears to be the implication of findings like those of Pong S. Lee, in "Structural Change in Rumanian Industry," Soviet Studies (October, 1968). Lee, following on work of Chenery, shows that industrial structure varies much more with per capita income and population size than with ideological systems.

${ }^{23} \mathrm{~S}$. Hirsch, Location of Industry and International Competitiveness (London, 1967). Vernon, "International Investment," 191-192.

34 Vernon, "International Investment," 193; and Vernon, Sovereignty at Bay, Chapter 3. 
link between such product innovations and exporting is also rather clear. Such products tended to be demanded in ever-increasing quantities in Europe, as income levels continually moved up toward the level prevailing previously in the U.S. What, however, would be the case in continental European countries, where potential innovators have long had a level of scientific and technical ability similar to that found in the highest income, U.S. market? ${ }^{35}$

A certain amount of product innovation designed to tap rising consumer incomes appears to have occurred in the European continent in spite of the tendency of the U.S. to lead. Nestlés mothers' milk substitute that allowed women to begin breaking away from their traditional ties to Kinder, Kirche, Kïche, was just the sort of product one might have expected to be a U.S. innovation in the $1890 \mathrm{~s}$ but was Swiss instead. ${ }^{38}$ And in at least one case, that of the Compagnie de Saint Gobain, a European firm obtained an innovative lead in income-elastic mirrors and glass in the early 1700 s, well before the U.S. existed as a nation. ${ }^{37}$

Still other European innovators seem to have directed their activity toward applying new processes to American-type, high income products. A number of observers have commented on the seeming tendency of American companies to innovate new products, whereas European firms tended to introduce new manufacturing processes. ${ }^{38}$ The available data are too fragmentary to show whether such a clear dichotomy between U.S. and European innovation existed. Nevertheless, examples suggest that process innovation was a major European theme. Philips of Holland and AEG of Germany even began life as independent entities in the 1890s by innovating processes for the production of Edison's product, the electric lamp. ${ }^{39}$

Nevertheless, most innovative activity undertaken on the Continent appears to have been oriented to ends other than timesaving products or processes for producing them. Distinctive patterns of distribution of income around the average per capita levels presented in Graphs 1 and 2 gave European innovators one set of unique stimuli. Patterns of relative factor costs that long diverged

\footnotetext{
35 It is generally agreed that there is little or no scientific gap among the countries under consideration here. The supply of technical ability does not seem to have been a significant constraint on innovation. See OECD, Gaps in Technology, various reports (Paris, 1971).

$30 \mathrm{~J}$. Heer, Reflets du monde, présence de Nestlé (Rivaz, 1966).

${ }^{37} \mathrm{~J}$. Choffel, St. Gobain, du miroir a l'atome (Paris, 1960).

38 This finding has been documented for the steel industry in Roger Emile Miller, Innovation, Organization and Environment: A Study of Sixteen American and West European Steel Firms (Université Catholique de Louvain, Belgique, Nouvelles Series, No. 86), 152.

3 Philips, Facts About Philips, 4-8.
} 
from those prevailing in the U.S. provided another. In the history of European innovation, these factors more than others appear to underlie the recurring emphasis on material-saving processes and substitutes and products designed for consumers with lower incomes than those prevailing in the U.S.

\section{Income Distribution and Comparative Innovation}

Over long periods of time, the pattern of distribution of personal income in most European countries has been notably unlike that prevailing in the U.S. Sociologists, historians, and business writers have often referred to the U.S. as a middle-class society. ${ }^{40}$ European countries, particularly the large continental countries, have often been described as societies composed of aristocratic and semiaristocratic elites on the one hand and peasants and workers on the other - without terribly many people in between. ${ }^{41}$ Table 7 suggests that such generalizations must be made with considerable care, and with attention to variations among European countries and among historical periods. In 1936, the middle classes in Nazi Germany were receiving a somewhat higher percentage of total personal income than the middle classes in the U.S., although contrasts were still in evidence at the high and low income levels. In the 1960s, Sweden, the Netherlands, the U.S., and also the U.K., came to have broadly similar income distribution patterns: in these countries similar percentages of total income went to the lowest 40 , the upper-middle 40 and the top 20 per cent of their populations. Nevertheless, clear contrasts between the U.S. and the largest European countries emerge from Table $7 .^{42}$ Moreover, one is struck

${ }^{40}$ See J. Fayerweather, International Marketing (Englewood Cliffs, N.J., 1965), 32. D. Krech, et al., Individual in Society: A Textbook of Social Psychology (New York, 1962), 304-316.

41 See Landes, Unbound Prometheus 48, 129, and 131 for such characterizations concerning the eighteenth and nineteenth centuries. See Ralf Dahrendorf, Society and Democracy in Germany (London, 1968), especially Chapter 6 for a recent characterization of this sort.

${ }^{42}$ The data presented in Table 7 are clearly imperfect. Different natural propensities in tax evasion and income declaration are but two of the many sources of potential error mentioned in the sources for that table. These data do not adjust for the effect on market demand of direct or indirect, progressive or regressive tax systems, nor do they account for government social security, insurance, and transfer payments. It is worth noting, however, that the United Nations Economic Commission for Europe, the source for many of the figures cited in Table 7, argues that after-tax and transfer payment adjustments do not have a major effect on the distribution patterns derived from before-tax data in the three countries for which estimates can be made: the U.K., Germany, and Norway. (Economic Commission for Europe, Incomes in Postwar Europe, Chapter 6.) The likely effect of such adjustments, could they but be made, would, of course, very likely accentuate the already favorable position of the lowest 10 per cent of European populations relative to that of the U.S. As tax evasion and underreporting of income tends to be a privilege of the rich, one might expect either a neutral effect across countries, or, if it is true that such 


\section{Table 7}

Distribution of Family Personal Income in Europe and the U.S. (Percentage of Total Income Before Tax Received by Indicated Fraction of Families )

\begin{tabular}{|c|c|c|c|c|c|}
\hline \multirow[b]{3}{*}{ Country \& Year } & \multicolumn{5}{|c|}{ Fraction of Families } \\
\hline & \multirow{2}{*}{$\begin{array}{l}\text { Lowest } \\
\text { Tenth }\end{array}$} & \multirow{2}{*}{$\begin{array}{c}\text { Lowest } \\
\text { Two } \\
\text { Fifths }\end{array}$} & \multirow{2}{*}{$\begin{array}{c}\text { Fortieth } \\
\text { to } \\
\text { Eightieth } \\
\text { Percentile }\end{array}$} & \multirow{2}{*}{$\begin{array}{c}\text { Highest } \\
\text { Fifth }\end{array}$} & \multirow{2}{*}{$\begin{array}{l}\text { Highest } \\
\text { Tenth }\end{array}$} \\
\hline & & & & & \\
\hline \multicolumn{6}{|c|}{ ABOUT THE TIME OF WORLD WAR I } \\
\hline US 1918 & $2 \%$ & $18 \%$ & $36 \%$ & $46 \%$ & $34 \%$ \\
\hline Germany 1913 & 3.5 & 18 & 27 & 55 & 41 \\
\hline \multicolumn{6}{|c|}{ DURING THE INTER-WAR PERIOD } \\
\hline US $\quad 1935-6$ & n.a. & 12.7 & 34.1 & 53.2 & 36 \\
\hline UK 1929 & 3 & 18 & 31 & 51 & 41 \\
\hline Germany 1936 & 1 & 11 & 36 & 53 & 39 \\
\hline Sweden 1935 & n.a. & n.a. & n.a. & 58.1 & 39.5 \\
\hline Netherlands 1938 & n.a. & n.a. & n.a. & 52.5 & 38.7 \\
\hline \multicolumn{6}{|c|}{ AROUND 1950} \\
\hline US 1950 & & 15.8 & 38.5 & 45.7 & 30.3 \\
\hline UK 1949 & n.a. & 17 & 35.5 & 47.5 & 33 \\
\hline Germany 1950 & 1 & 12.5 & 39.5 & 48 & 34 \\
\hline Sweden 1948 & n.a. & 12.8 & 40.6 & 46.6 & 30.3 \\
\hline Netherlands 1950 & 1.3 & 13.8 & 37.2 & 49 & 35 \\
\hline \multicolumn{6}{|c|}{ DURING THE $1960 \mathrm{~s}$} \\
\hline US 1969 & 1 & 15 & 40 & 45 & 27 \\
\hline UK 1964 & 2 & 15.3 & 40.5 & 44.2 & 29.3 \\
\hline Germany 1964 & 2.1 & 15.4 & 31.7 & 52.9 & 41.4 \\
\hline France 1962 & 0.5 & 9.5 & 36.8 & 53.7 & 36.8 \\
\hline Sweden 1963 & 1.6 & 14 & 42 & 44 & 27.9 \\
\hline Netherlands 1962 & 1.3 & 14 & 37.6 & 48.4 & 33.8 \\
\hline
\end{tabular}

Note: The percentages for the fortieth to eightieth percentiles are highlighted to call attention to the fraction of incomes received by what most observers might be inclined to refer to as the "middle-class."

Sources: For the U.S. in 1918: Wesley C. Mitchell and others, Income in the United States: Its Amount and Distribution, 1909-1919 (1921), I, 141. For Germany in 1913, the U.K. in 1929, and the U.S. in 1935-1936: W. S. and E. S. Woytinsky, World Population and Production (New York, 1953), 409, 407. For Germany, Sweden, and the Netherlands in the 1930s, and for the U.K., Germany, Sweden, and the Netherlands in the $1940 \mathrm{~s}$ and in 1950: United Nations, Economic Commission for Europe, Economic Survey of Europe in 1956 (Geneva, 1957), chapter IX, 6. For the U.S. in 1950 and 1969: U.S., Department of Commerce, Statistical Abstract of the United States 1971 (Washington, 1972), Table 504, p. 317, For European countries in the 1960s: United Nations, Economic Survey of Europe in 1965, Part 2: Incomes in Postwar Europe-A Study of Policies, Growth and Distribution (Geneva, 1967), chapter 6, p. 15.

activities are rather more European than American hobbies, they would once again merely emphasize the contrasts to which Table 7 points. 
by the persistence of the basic patterns. The resemblance between the German and U.S. distributions of 1964 and those of 1913 is a case in point. ${ }^{43}$

These contrasts in income distribution made the home environments in which European multinationals were born clearly different from that which nurtured U.S. multinational enterprise. Where markets diverged, innovations were introduced accordingly, and distinctive oligopolistic strengths were developed. As the history of the auto industry was to show, European companies tended to introduce either luxury products or near-necessities for the masses. U.S. firms were pulled toward satisfying middle and upper-middle income needs. ${ }^{44}$

Daimler and Benz first marketed workable automobiles in Germany in 1888 and 1886. Conditioned then and later by their home market demand, "the German manufacturers concentrated on luxury cars, since the German middle class was not large enough to support the scale needed for the innovation and manufacture of an inexpensive automobile." 45 For French auto manufacturers before World War I, the market demand was much the same. One examination of the market for automobiles between 1899 and 1928 in the French Département of Indre-et-Loire led to the conclusion that "the demand for private automobiles comes principally from the group comprising people of independent means, noblemen and large land-owners." 40 A government report in 1917 went even further. It argued that past successes meant that the orientation of the French industry to luxury demands ought to be elevated to the level of doctrine: "It is the luxury article that has given birth to our worldwide reputation. . . . we must defend this patrimony . . . it is this that has led to the development of our automobile industry. . . . purity and harmony of form, even more than luxury

${ }^{4}$ Dr. Emilio Fontela and others of the Batelle Institute in Geneva, Switzerland have published a number of discussions of income distribution in Europe in which cogent arguments are presented for the existence of a relationship between increases in average per capita incomes and moves toward the U.S. type of income distribution. Their hypothesis is that as economic growth proceeds, markets of masses-plus-aristocrats will be replaced by markets in which a middle class, itself having a wide range of incomes, will constitute the dominant market segment. The long-term data presented in Table 7 provide little evidence in favor of such a hypothesis. See H. L. Dotti and Emilio Fontela, "Distribution des revenues et intégration de l'Europe," Revue du Marchê Commun (Janvier, 1970).

14 For brief but comprehensive summaries of the history of the auto industry, see B. McKern, "The U.S. Automobile Industry in the World Market," in R. Vernon, Manager in the International Economy (Englewood Cliffs, N.J., 1972); L. T. Wells, Jr., "National Policies in International Industry: The Europeans and the Automobile," forthcoming in $R$. Vernon, ed., Big Business and Governments in Europe (Cambridge, Mass., 1974).

45 Wells, "National Policies," 4.

16 Fridenson, Histoire des Usines Renault, 21. 
manufacture, must be one of the primordial elements of the maintenance of our supremacy." 47

It was not until the automobile was uprooted from Europe, in the manner of the jet engine, the computer, penicillin, the aerosol can, the continuous strip mill, and other inventions, that it was introduced into the huge U.S. market. By accident rather than design, the low price (then) middle class U.S. market was discovered when one of the factories of Ransom Olds burned down. The only car he could produce was the least expensive of his line. The demand turned out to be enormous. When Olds was unable to finance the expansion of the Oldsmobile, Ford stepped in with the mass-produced Model $\mathrm{T}$ in 1908 and the moving assembly line in 1914. ${ }^{48}$ It was during these years that U.S. production and exports outstripped those of Germany and France. ${ }^{49}$ But France and Germany were exceeded in products that had little else but the name "automobile" in common.

Much later, in 1970, continental European auto production was once again to equal that of the Americans. ${ }^{50}$ In addition, Europe's auto exports in the $1950 \mathrm{~s}, 1960 \mathrm{~s}$, and $1970 \mathrm{~s}$ were to be vastly greater than those of America. ${ }^{51}$ The oligopolistic advantages that underlay these developments, however, had much to do with mass markets consisting largely of customers with incomes still lower than those that had tempted American producers. In 1946, following nationalization, Renault introduced its low price R-4. ${ }^{52}$ Then came Citroën's 2-CV. ${ }^{53}$ Shortly thereafter came the market introduction of Germany's Volkswagen. ${ }^{54}$ Automobiles all, but of a very different sort than those which set U.S. manufacturers on the path to multinationality. Indeed, it was not until the late 1960s that the introduction of Citroën's GX and Volkswagen's Audi gave hints that perhaps broad middle-class markets were beginning to become significant on the Continent.

Developments in other industries, it appears, often paralleled European-U.S. contrasts in automobiles. The comparatively favorable income position of the lowest classes plus the introduction of social insurance legislation as early as the 1880 s meant that European (and particularly German) companies were to lead in

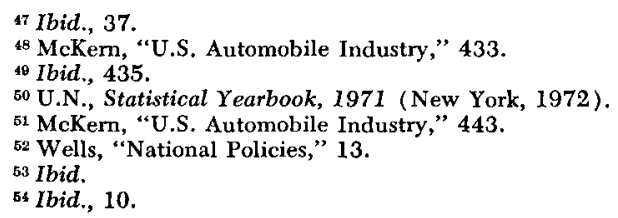


basic pharmaceuticals. ${ }^{55}$ As a recent study noted, "Germany was not alone in having the technology to translate a laboratory synthesis into a full-scale operating production operations. Both England and France had strong chemical industries, capable of producing what was discovered in Germany. The missing ingredient [in these former countries] was demand." 56 Important U.S. pharmaceutical companies emerged only after World War II. They then made their distinctive contribution in antibiotics and psychopharmaceuticals. These U.S. innovations apparently reduced hospitalization time, but they were probably less important than aspirin, novocaine, and entero-vioform for stomach upsets - all introduced in Europe by Bayer, Hoechst, and Ciba before World War I. ${ }^{57}$

The phenomenon of European, and especially Italian, specialization in small household appliances and American company dominance in large models also seems related to differences in income distribution, as well as to those in income levels. ${ }^{58}$ Although the companies that produce timepieces are too small to be among those systematically included in this study, the split in the world watch industry between Swiss producers of luxury goods and U.S. middle class, mass merchandisers, seems another variation on the auto industry theme. ${ }^{59}$

\section{Relattve Factor Costs and Innovation}

Perhaps, however, the distinctive histories of European and American commercial innovation have been most conditioned by persistent international differences in the relationship between labor costs and the costs of other production inputs. The most obvious transatlantic contrast has been in comparative ratios of labor to rawmaterial costs. Quantitative and impressionistic historical sources are in accord. Save for partial exceptions such as resource-endowed

\footnotetext{
${ }^{55} \mathrm{~L}$. Wortzel, "The Pharmaceutical Industry Study: An Overview," unpublished ms., presented at a conference sponsored by the Agnelli Foundation in Turin, Italy on the Comparative Multinational Enterprise Project, June, 1971.

58 Ibid., 11.

${ }^{87}$ Haber, Chemical Industry In the Nineteenth Century.

${ }^{58}$ L. T. Wells, Jr., "Test of a Product Cycle Model of International Trade: U.S. Exports of Consumer Durables," Quarterly Journal of Economics (February, 1969).

59 Harvard Business School, "Note on the Watch Industries in Switzerland, Japan and the United States," 1972. Dotti and Fontela, "Distribution," point out that income level and distribution differences among nations will lead to differences in market demand structure across industries as well as within industries. These factors may explain, for example, why there have been so few innovations, large firms, or multinational firms in food processing arising on the European continent. As yet, the hypothesis has not been systematically
} tested. 
Sweden and colonial Belgium, European entrepreneurs have faced the cost consequences of a relative scarcity of land and raw materials. U.S. entrepreneurs have been, and remain, faced with an environment in which labor commands a relative premium because of its scarcity.

Table 8 presents quantitative estimates of these differences in relative costs for the years 1913, 1929, 1950, 1963, and 1971. The estimates are crude, but the orders of magnitude shown are in broad accord with what qualitative sources tell us of differences among countries and in different periods of time.

\section{TABLE 8}

International Comparisons of Ratios of Raw Material to Labor Costs, 1914-1971

(APPROXIMATE RELATIVE COST OF ONE ARBITRARY UNIT OF RAW MATERIAL TO THE COST OF ONE HOUR OF LABOR WITH THE U.S. RATIO OF MATERIAL TO LABOR COSTS TAKEN AS 100.)

\begin{tabular}{lccccc}
\hline \hline & 1913 & 1929 & 1950 & 1963 & 1971 \\
\hline U.S.A. & 100 & 100 & 100 & 100 & 100 \\
Belgium & & 136 & 176 & 330 & 263 \\
France & 194 & 180 & 448 & 460 & 364 \\
Germany & 294 & 356 & 290 & 290 & 190 \\
Italy & & 524 & 502 & 460 & 345 \\
Netherlands & & 224 & 420 & 370 & 251 \\
Sweden & 158 & 144 & 113 & 180 & 139 \\
Switzerland & & 144 & 181 & 210 & 182 \\
\hline
\end{tabular}

\footnotetext{
Method of Calculation:
}

Historical information concerning prices paid for raw materials by entrepreneurs within national markets is difficult or impossible to obtain. Price series, such as they are, tend to be based on public quotations on international markets, like the London Metal Exchange. Thus, they were not useful for our purposes. National indices of raw materials prices, however, were readily available, as were indices and values for wage rates. If one assumed that in any given year, a relatively open, one-price international market in raw materials prevailed, it then became possible to derive indicators of earlier or subsequent divergences in relative factor cost ratios based on domestic price indices. In this table, it is assumed that 1963 was such a year, and that raw materials' prices were identical in all markets. Wage and price series were first put on a comparable $1963=100$ basis. Wage indices were then adjusted to reflect differences in wage levels among countries in 1963 , i.e., since the $S$ wedish average wage rate was equal to 57 per cent of that in the U.S. in that year, the whole Swedish series was adjusted in proportion to this difference. This meant that the Swedish index was shifted 43 per cent lower to reflect absolute U.S.Swedish differences. It did not mean that the margin between Swedish and U.S. revised indices was ever at 100:57 in any year other than 1963. Once this adjustment was made, wage and raw materials' price indices could be treated as if they were money-price series. One arbitrary unit of raw materials could be said to cost whatever one average hour of labor cost in the U.S. in 1963. National materials "cost series" were divided by the adjusted labor cost series and the resulting ratios proportioned to the base of U.S. $=100$ shown in the table.

Sources: U.N., Statistical Yearbook, various issues, for 1929-1971 data on hourly earnings and raw material costs. International Labor Organization, Year Book of Labor Statistics, various issues. 
Throughout the twentieth century, indeed from its earliest days as a nation, the U.S. had comparatively little labor relative to its abundant land and material resources. ${ }^{60}$ Prior to World War I, neither the slave trade nor successive waves of immigration seemed to make much of a dent in this fact of life facing the U.S. entrepreneur. $^{61}$ With the passage of restrictive immigration laws in 1917,1921 , and 1924, the relative scarcity of labor was aggravated even further. ${ }^{62}$

In Europe, and particularly on the Continent, labor was long in substantial surplus. ${ }^{63}$ From the mid-1800s to the 1960 s, most of Europe worried about what to do with its reserve army of the unemployed. The scarce resources in Europe were neither hands nor brains - they were raw materials. This scarcity was sometimes relieved by trade or colonial expansion, but the fundamental, autarkic reflexes first nurtured by Colbert under Louis XIV in the seventeenth century continually re-asserted themselves as successive European governments declared their dependence on foreign supply to be politically and militarily intolerable. The result was a concern for substitution, and saving, of raw materials that recurred again and again in European history. Innovation of synthetic nitrogenous fertilizers, dyestuffs, rubber, and artificial silk, or rayon, constituted one sort of response to the stimuli provided in such markets. Products and processes that saved fuel were another. European firms, for example, pioneered in high efficiency auto engines, electric furnaces, and fuel injection apparatus, as well as in industrial processes such as that of Solvay for soda-ash, and of Pechiney for producing aluminum with high-cost electricity. Similar examples abound in the history of relative factor costs conditions in Europe and their relation to innovations. ${ }^{64}$

\section{Conclusions}

Much remains to be done in the study of European multinational manufacturing before a complete picture can emerge. One area that needs to be explored, for example, concerns the contrasts between American and European firms' motivations for switching

${ }^{60}$ H. J. Habakkuk, American and British Technology in the Nineteenth Century (London, 1962), especially chapter 3 .

61 “Immigration Law," Encyclopaedia Britannica (New York, 1973), $1106 \mathrm{ff}$.

62 Ibid., 126-131. 43.

${ }^{*}$ See, for example, A. V. Desai, Real Wages in Germany 1871-1913 (London, 1968),

64 For more details, see Chapter II of the author's forthcoming book, The Other Multinationals: The International Firms of Continental Europe, 1870-1970. 
from exporting to foreign manufacturing. This is all the more so since tariffs and other trade restrictions like exchange controls, quantitative quotas, patent-working regulations, and subsidies appear to have been the primary influence on the decisions of European firms to manufacture in, rather than export to, foreign markets. Such government-imposed restrictions often triggered foreign production of the material-saving innovations emphasized above. Government measures appear to have been much less important in the spread of foreign manufacturing of the income-elastic products carried forth by American multinational enterprise. The lenient attitude long held in Europe toward cartels, mergers, and other private agreements also seems to have affected the amount and form of foreign activity by continental firms. Points of similarity between the American and European multinational spread, may, however, exist in the history of the internationalization of production of Europe's low-income mass products, such as autos and pharmaceuticals, into the less developed world. These and other factors require examination before we can arrive at a comprehensive treatment of the multinational firms of continental Europe, but they cannot be considered in detail here. ${ }^{65}$

The present paper has sought to contribute to an understanding of the origins of the multinational manufacturing enterprises based on the European continent. Those enterprises followed a different path of development from that pursued by United States firms, but European multinational manufacturing began even earlier than did American, and its story is no less significant. Beginning with Cockerill's 1815 plant in Prussia, European companies engaged in important manufacturing activity, mostly in other European nations. Rather than the relatively even pattern of the spread of United States enterprises abroad, European firms tended to expand in spurts and then to undergo periods of stagnation. They were especially active in the years just before and after World War I, and in the post-World War II period.

Throughout a century and a half of multinational production, European companies followed several basic patterns. In most cases, a firm would innovate a product or process (usually the latter), thereby securing an oligopolistic advantage which it would initially exploit by marketing in other countries and would finally end up manufacturing inside those countries. The particular kinds of products and processes innovated by European multinationals tend-

\footnotetext{
${ }^{65}$ More analysis and data will be contained in the author's forthcoming book, The Other Multinationals.
} 
ed to be influenced by the distinctive nature of income levels and income distribution in their home markets, and by the relative factor costs. Europe's evolution of a luxury market side-by-side with a large lower class market, and its historical lack of a large middle class market like the United States, was of major significance. Similarly, the abundance of labor and the shortage of raw materials in the western part of the European continent played a large role in shaping patterns of product and process development. The result of such factors was an evolutionary pattern distinct from the United States experience in many ways but rich in its own lessons about the history of multinational enterprise in the modern world. 